Article

\title{
Protecting Infrastructure and Public Buildings against Sea Level Rise and Storm Surge
}

\author{
Paul Chinowsky ${ }^{1, *}$ and Jacob Helman ${ }^{2}$ \\ 1 Program in Environmental Design, University of Colorado Boulder, Boulder, CO 80309, USA \\ 2 Resilient Analytics, Inc., Louisville, CO 80027, USA; jhelman@resilient-analytics.com \\ * Correspondence: paul.chinowsky@colorado.edu
}

Citation: Chinowsky, P.; Helman, J. Protecting Infrastructure and Public Buildings against Sea Level Rise and Storm Surge. Sustainability 2021, 13, 10538. https://doi.org/10.3390/ su131910538

Academic Editor: Nyuk Hien Wong

Received: 8 August 2021

Accepted: 20 September 2021

Published: 23 September 2021

Publisher's Note: MDPI stays neutral with regard to jurisdictional claims in published maps and institutional affiliations.

Copyright: (c) 2021 by the authors. Licensee MDPI, Basel, Switzerland. This article is an open access article distributed under the terms and conditions of the Creative Commons Attribution (CC BY) license (https:// creativecommons.org/licenses/by/ $4.0 /)$.

\begin{abstract}
The national study analyzes sea level rise (SLR) impacts based on 36 different SLR and storm surge scenarios across 5.7 million geographic locations and 3 time periods. Taking an approach based on engineering design guidelines and current cost estimates, the study details projected cost impacts for states and cities. These impacts are presented from multiple perspectives, including total cost for constructing seawalls, costs per capita, and costs per square kilometer. The purpose of the study is to identify specific locations where infrastructure is vulnerable to rising sea levels. The study finds that Sea Level Rise (SLR) and minimal storm surge is a USD 400 billion threat to the coastline of the lower 48 United States by 2040 that includes a need for at least $80,000 \mathrm{~km}$ of protective barriers. The research is limited in its scope to protecting coastal infrastructure with seawalls to enable consistency throughout the study. The study is original in that it is an effort across the lower 48 states to identify infrastructure that is vulnerable, as well as the cost associated with protecting this infrastructure.
\end{abstract}

Keywords: sea level rise; climate change; infrastructure; coastal engineering

\section{Introduction}

Climate change presents a wide range of challenges for infrastructure owners, planners, and users. Of these potential impacts, the one that is predicted to have one of the largest ramifications in the United States, is Sea Level Rise (SLR). If a rising temperature continues to manifest on a global scale, then sea level rise will occur mainly due to a combination of thermal expansion of sea water and the melting of land-based ice into the ocean [1]. The consequences of this sea level rise on coastal road networks, buildings, and infrastructure due to economic, social, and environmental costs are predicted to be substantial [2-4].

According to the National Oceanic and Atmospheric Administration (NOAA), the United States' tidal shoreline is 153,645 km long [5], of which 97,111 km is along the lower 48 states. Estimates for the number of people that could be impacted by SLR vary, based on the expected depth associated with the SLR, but range from a potential 4.2 million people at immediate risk of inundation to 13.1 million people at extreme risk in the year 2100 [6].

For the median estimates of SLR at 2100, Ref. [7] propose a likely range of 49-174 cm for the $17-83 \%$ likelihood interval and a likely range of $36-238 \mathrm{~cm}$ for the $5-95 \%$ likelihood interval, depending on the progress in mitigating greenhouse gas emissions. The alternatives considered are a $+2{ }^{\circ} \mathrm{C}$ stabilization scenario and the no-mitigation option. In 2050, the corresponding intervals are 22 to $47 \mathrm{~cm}$ and 16 to $61 \mathrm{~cm}$. On the other hand, [8] indicate a likely range of $20-139 \mathrm{~cm}$ at 2100 and of $13-35 \mathrm{~cm}$ at 2050 for the $10-90 \%$ likelihood interval (qualitatively extrapolated from their Figure $2 b$ ) for a set of scenarios that range from the fixed present-rate of SLR (which is slower than that implied by any mitigation option) to the no-mitigation reference. In either study, the estimated rates of SLR start to diverge by the 2050s. 
Because coastal areas have historically been attractive areas to establish communities, the predicted SLR leaves many systems along the coast vulnerable to damage. A total of $96,560 \mathrm{~km}$ of US roads and bridges in the existing coastal floodplain are already at risk to extreme storms and hurricanes [2]. When put in perspective of the overall US economy, coastal zone counties account for $48 \%$ of the Gross Domestic Product (GDP) or USD 8 trillion dollars [9].

The size and extent of this threat is focusing discussions on the question of what should be done to protect coastal communities from the threat of sea level rise and the associated greater floodwater depths. This discussion crosses the political, economic, and engineering domains as the question emerges as to the appropriate approach that should be taken in response to the threats [10-13]. While the scientific determination of what areas are at the greatest risk continues to dominate the discussion, the challenge of how to respond to this vulnerability requires greater attention. Specifically, the question of whether SLR vulnerability requires new policies to relocate communities, new investments to construct protection barriers, or whether communities should take a wait-and-see approach is one that needs further attention.

Currently, the approaches to the SLR response can be divided into three broad categories: protection, accommodation, and retreat. The protection category includes creating dikes, surge barriers, closure dams, constructing dunes, nourishment and sediment management of wetlands, creating coast defenses, sea walls and land claims, creating saltwater intrusion barriers, and implementing drainage systems/polders. The accommodation category includes implementing building codes to minimize the flooding of critical building spaces, ensuring land use planning that accommodates for wetland loss, changing water extraction practices, using freshwater injections to stop saltwater intrusions, and increasing the delineation of natural hazard areas. Finally, practices that pertain to retreating focus heavily on policies that minimize new building in areas where SLR threatens infrastructure, as well as considering the movement of existing structures in threatened areas [1].

While protection, accommodation, and retreat present a large array of approaches to protecting against SLR, historically, the implementation of sea walls, also known as rock revetments, or armoring, has been the most common approach to reducing the impact of ocean activity on coastal communities [14,15]. Similarly, the building of inland sea walls, also known as bulkheads, along the banks of inland waterways have been a common approach to protecting property against rising waterway levels. While these are the predominant approaches to protecting coastal properties, seawalls do not work in every circumstance. Specifically, in cases where porous materials such as limestone form the bed of the waterway, water can infiltrate through the rock and under the seawall. In these cases, alternatives, including the addition of pumping, may be necessary.

Based on the historic focus on seawalls as a protection strategy, the current study provides an estimate of the construction costs associated with armoring areas of the coast that are projected to be flooded and which contain built assets within the lower 48 states. These assets include both public and private assets such as roads, rails, and public buildings. Private residences are not specifically modelled in this effort but are included indirectly by protecting the locations that include roads and other public infrastructure elements that support these properties.

The intent of the current study is to provide the best estimate of expenses that have the highest likelihood of being incurred by 2040. These estimates are necessary as researchers have not published a study with a similar scope focusing on the costs of protecting coastal infrastructure along the lower 48 states from SLR.

\section{Literature Review}

The analysis of sea level rise impact is a growing field of study. A variety of approaches have been used to model the potential economic, social, and environmental costs created by sea level rise. These procedures vary in their methodologies used, geographies assessed, and scales implemented. 
The first class of models consists of systems that are used to predict and model the amount of land along the coastline that will be inundated, which may include inundation models and Sea Level Affecting Marshes Model (SLAMM) [16]. Inundation models utilize climate models to predict what areas will be flooded, using Geographic Information Systems (GIS) and Digital Elevation Models (DEM). SLAMM specializes in incorporating habitat changes and processes that are likely to be impacted by climate change. Kirshen et al. take a more simplified approach to modeling the impacts of sea level rise by "developing damage-flooding depth probability exceedance curves for various scenarios over a given planning period and determining the areas under the curve" [17].

Neumann at el. incorporate "a tropical cyclone simulation model, a storm surge model and a model for economic impact and adaptation" to estimate the impacts of sea level rise for the US coastline through 2100 . The model integrates site-specific elevation, land subsidence, and property values to estimate the costs incurred due to shoreline armoring, beach nourishment, and property abandonment. Neumann et al. identify that those coastal areas are densely populated, further intensifying the impact of sea level rise on human populations [18-20].

In addition to measuring the financial impact of land inundation, ecological landscape spatial simulation models account for the detrimental environmental consequences of SLR. The Ecological landscape spatial simulation models are a category of model that broadly analyze environmental factors such as subsidence, sea-level rise, changes in river discharge, and climate variability and their impacts on coastal habitats. These models are able to incorporate a larger range of variables, including "coastal and estuarine hydrodynamics, water-borne particle transport, vegetation growth and infrastructure risk". However, due to this level of detail, these models can be expensive and time-consuming to run. The Dynamic Interactive Vulnerability Assessment (DIVA) model integrates biophysical and socioeconomic consequences of sea-level rise and is able to assess the costs and benefits of adaptation to the predicted impacts. DIVA is designed to incorporate a large variety of factors and components at a global scale and size. Similarly, SimCLIM models the biophysical and socioeconomic impacts of climate change and variability. The tool estimates how future climate and sea-level changes impact sectors and associates a sensitivity analysis with the modeling. The tool can be applied to local and global scales, depending on the availability of data.

The final category of model used to predict and understand the impacts of SLR account for the social impact on coastal communities and economies. Hsiang et al. utilize SEAGLAS (Spatial Empirical Adaptive Global-to-Local Assessment System) to estimate the cost of climate change to the sectors of agriculture, crime, coastal storms, energy, human mortality, and labor using a "risk-based approach", which is "grounded in empirical longitudinal analyses of nonlinear, sector-specific impacts". The results suggest that climate change costs approximately $1.2 \%$ of the gross domestic product per $+1{ }^{\circ} \mathrm{C}$ [21].

\section{Methods}

Building on existing methodologies, as well as new approaches developed for the current study, the current study employs a multi-step process incorporating climate projections, geoprocessing of detailed coastline flooding maps, the computational assessment of where coastline needed protection, and the calculation of the costs associated with this protection. The process developed for this estimation is based on previous climate impact work developed by the authors for infrastructure impacts locally, regionally, and globally [22-24].

\subsection{SLR and Storm Surge Projections}

The study utilized SLR and 1-year storm surge inundation projections from Climate Central through high-resolution datasets for the lower 48 states [25-27]. The datasets included analysis of the coastline at a $5 \mathrm{~m} \times 5 \mathrm{~m}$ grid to ensure accurate capture of tidal inlets. Each geographic location provided information on whether the location was projected to be inundated and, if so, to what depth the inundation was expected.

The inundation dataset included alternative projections from the two lower projection Representative Concentration Pathways (RCP), RCP 2.6 and RCP 4.5. Based on the consid- 
erations of [28] for our cost assessment, we focused on the two lower-end scenarios RCP 2.6 and RCP 4.5, while only presenting results for RCP 4.5, as the closest to the emission path followed so far, as well as to the trajectory determined by current mitigation policies up to 2040.

The inundation datasets provided for the study were derived from a Monte Carlo simulation set of 10,000 projections generated by Climate Central. Specifically, the 5th, 50th, and 95th percentile inundation projections for each of the two pathways from the overall dataset were selected for the current study. Three time periods were selected from the results for the impact analysis: 2040, 2060, and 2100. Additionally, inundation was included with and without 1-year storm surge projections to capture both the base SLR impact and the potential for regular flood impacts.

Similar to the projection data, Climate Central provided GIS files of infrastructure locations based on previous work and public database information [28]. This infrastructure included a broad range of public infrastructure including schools, hospitals, medical facilities, government buildings, airports, and all public horizontal infrastructure (roads, railways, and runways). Although the study does not consider private residences directly, the location of most residential areas can be determined through the location of public roads that are used to access residential areas. Therefore, by considering all areas that contain a road (both paved and unpaved), the majority of residential areas were considered. National parks and protected wildlife areas with limited access roads were not included in the study.

\subsection{Geoprocessing}

The first step in the impact assessment was the identification of areas where inundation and flooding propagated along the coastline and inland waterways. A transformation of the dataset was performed to reduce the information to indications of whether infrastructure was in a specific area, and whether that area was projected to be impacted by SLR or storm surge. Although the original climate dataset was provided at an ultra-high resolution, for processing speed, usability and accuracy, the dataset was condensed to a uniform grid size. Sensitivity analysis tests were performed to determine an appropriate grid size that would allow for the most accuracy in results while still maintaining computability speed. The sensitivity analysis focused on determining the largest grid size that would both retain the underlying inundation detail as well as accurate location information for the infrastructure being analyzed. Through a series of test runs of increasing grid sizes, the sensitivity analysis found that a horizontal grid system of $150 \mathrm{~m}$ would achieve the research objectives (Figure 1).

\subsection{Protection Assessment}

Once the flooding files were processed, the second step of the process required determining what areas of coastline needed protection to remove the threat of flooding. This determination requires a series of logic tests to understand if a flooded grid is directly impacted by flooding from adjacent waterways or if it is indirectly affected by other grids that are adjacent to waterways.

The first step in this process was to determine if any given gridded square is located within an area that is expected to flood, according to a specific climate scenario. This question is nuanced in that there must be a determination as to the minimum inundated fraction for a grid cell to be considered flooded. The need for this determination originates from the issue of how to limit the protection of coastal grids that appear in the study with minimal flooding along the edge of the coastline. For example, a grid covering an inlet which is indicated to have inundation over an area covering just a few yards onshore and does not include flooding of any infrastructure can be eliminated in terms of needing protection. The study adopted a threshold of $15 \%$ minimum inundation area to eliminate overprotection scenarios. The value of $15 \%$ was chosen based on engineering judgement upon inspection of protection patterns using $5 \%, 10 \%, 15 \%$, and $20 \%$. 


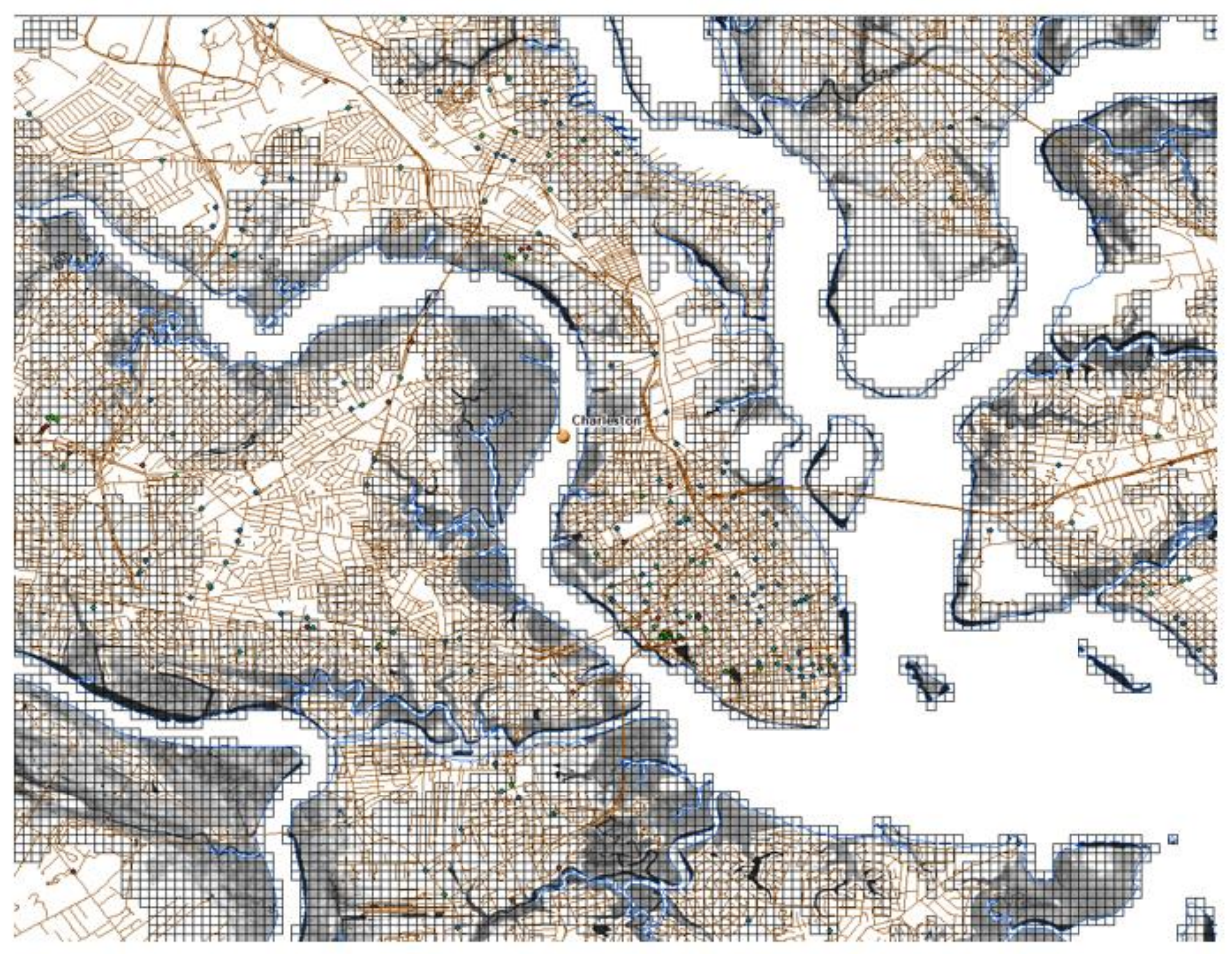

Figure 1. The $150 \mathrm{~m} \times 150 \mathrm{~m}$ grid used as the basis for analyzing the coastline is overlayed on the infrastructure and inundation zones. Each grid isolates information on the projected flooding and the infrastructure in that grid to determine length of protection required within each grid.

The second issue focused on whether a grid was flooded due to direct flooding or indirect flooding. The model works from the assumption that wherever flooding occurs, the shoreline directly impacting that flooded area needs to be protected. The case of direct flooding occurs when a grid is adjacent to a waterway and the scenario indicates that grid is flooded due to an overtopping of the adjacent waterway. In this case, the adjacent shoreline needs to be protected to prevent the grids from incurring flooding. The indirect case occurs when an inland grid is flooded due to being connected directly or indirectly to a water-facing grid. In this case, the model must trace the path of the flood back to its origin, which is the grid adjacent to the coastline. This tracing is accomplished by analyzing adjacent grids for flooding. Each time a grid with flooding is detected, adjacent grids are analyzed to determine which may be flooded. This process continues until a coastal grid is detected. The model then protects the coastline adjacent to the grid to eliminate the threat to the whole exposed area.

The identification of the flood areas provides the entry point for the final step in the process of calculating the length of coastline to be protected. The current study utilizes NOAA Medium Resolution Shoreline Data to determine what is considered shoreline. This dataset does not include Hawaii, Alaska, Puerto Rico, Guam, or other US territories. However, the dataset was selected to ensure that the results were consistent with the original dataset provided by Climate Central, which was based on the NOAA Medium Resolution Shoreline Data. As illustrated in the map of Charleston, South Carolina in Figure 1, detailed imaging of the inlets and tidal areas resulted in a high-resolution map where the actual length of coastline increased, in some cases significantly, from traditional coastline figures that emphasize only direct coastal exposure. Charleston is used as an example for two reasons: (1) the Charleston area was used as an initial benchmark of the methodology, as a comparison could be made with existing estimates and designs published for the Charleston area, and (2) the complexity of the Charleston coastline enabled the researchers to look at a complicated case as a foundational case. The methodology employed after this benchmarking effort is a notable advancement in understanding the 
protection requirements for coastal communities as it gives a more accurate estimate of the protection requirements. This high resolution translated to a study length of approximately $217,000 \mathrm{~km}$ of potentially exposed coastline.

After completing the protection length calculation, the model analyzed the coastline for every grid that was determined to have a flooding impact on identified infrastructure. For each of the identified grids, the length of coastline in that grid was calculated to a linear meter (Figure 2).

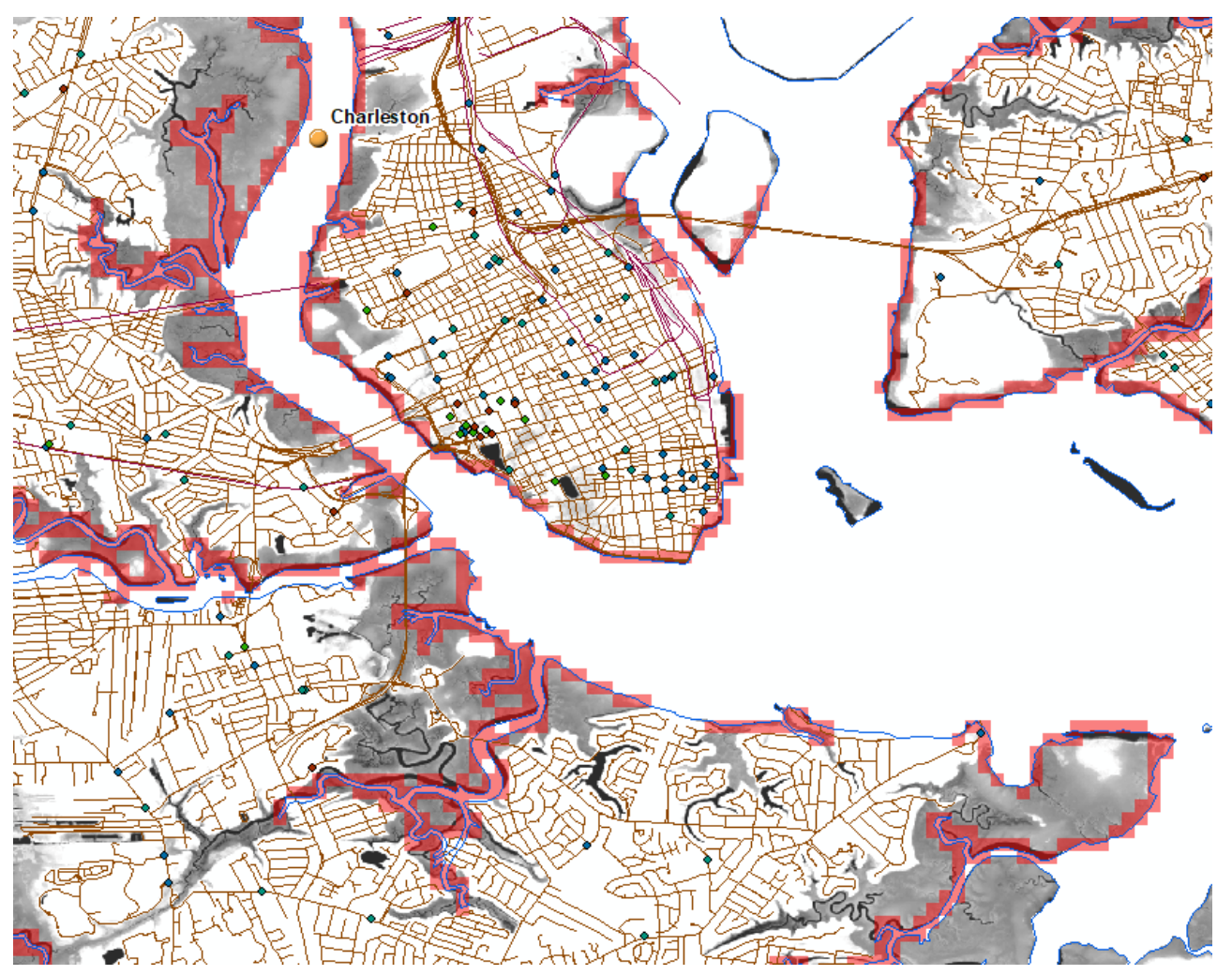

Figure 2. The $150 \mathrm{~m} \times 150 \mathrm{~m}$ grid overlayed on the infrastructure and inundation zones combined with the projected protection zones. Each red grid indicates an area requiring protection. The blue lines indicate shoreline.

\subsection{Costing}

Costing assessments for the study were created using a combination of national cost data [29] and local estimates from seawall design and construction companies to establish localized per-meter costs. This combination provided a national baseline through the published data, as well as local specificity provided through individual project data. In this manner, the estimates were adjusted for location factor by state, based on the location of the sea wall.

The cost estimates are divided into two categories, coastal seawalls and inland seawalls. In terms of the former, coastal seawalls are comprised of armored revetments that are either adjacent to shore structures or serve as standalone offshore structures. The current study utilizes a typical design approach of using field stone to create an armored revetment on the shoreline. This design is utilized in the model wherever the coast exposure is direct to open water. Where the protection assessment determined that seawalls were required in an area that had direct ocean exposure, the linear meters of seawall required is multiplied by the per-meter cost of the revetment.

Inland seawalls, often referred to as bulkheads, focus on the protection of shoreline from an increased water level as well as from indirect wave action. Bulkheads are generally constructed of steel sheet piling, wood, or concrete where more permanent protection 
is required. The primary cost factor in these solutions is the installation, which may vary depending on where the bulkhead is located. Similar to the revetments, where the protection assessment determined that inland protection was required, the per-meter cost of the bulkhead is multiplied by the total length of the protection required.

When the estimates for the two types of potential protection devices are combined, the overall costing Equation (1) can be written as follows:

$$
\mathrm{C}_{\mathrm{T}}=\left(\left(\mathrm{C}_{\mathrm{R}} * \mathrm{~L}_{\mathrm{R}}\right) * \mathrm{LF}_{\mathrm{R}}\right)+\left(\left(\mathrm{C}_{\mathrm{B}} * \mathrm{~L}_{\mathrm{B}}\right) * \mathrm{LF}_{\mathrm{B}}\right)
$$

where:

$\mathrm{C}_{\mathrm{T}}=$ Cost Total (USD);

$\mathrm{C}_{\mathrm{R}}=$ Cost Revetment (USD);

$\mathrm{C}_{\mathrm{B}}=$ Cost Bulkhead (USD);

$\mathrm{L}_{\mathrm{R}}=$ Local Cost Factor Revetment (change from national cost per meter);

$\mathrm{LF}_{\mathrm{R}}=$ Linear Meters of Revetment;

$\mathrm{L}_{\mathrm{B}}=$ Local Cost Factor Bulkhead (change from national cost per meter);

$\mathrm{LF}_{\mathrm{B}}=$ Linear Meters of Bulkhead.

Returning to the Charleston, SC example, the costing methodology, when combined with the variance in model projections, results in a range of possible outcomes. Tables 1 and 2 detail the range of results for Charleston across the scenarios and time slices. Table 1 indicates the costs for SLR alone while Table 2 includes the additional costs when a one-year storm surge is considered. While the results presented in this paper emphasize the 2040 time slice with the 50th percentile from RCP 4.5, the full range of alternative projections were analyzed. The tables provide a representative example of the variance that exists for specific coastal locations with local variances occurring due to local geographic attributes.

Table 1. The cost in millions USD for protecting Charleston, SC under the different scenarios considered in the study. The variance is representative of that which exists for each location considered. The range of the variance is dependent on local conditions along the coastline.

\begin{tabular}{ccccccc}
\hline & \multicolumn{3}{c}{ RCP 2.6 } & \multicolumn{3}{c}{ RCP4.5 } \\
\hline $\begin{array}{c}\text { Likelihood (in terms } \\
\text { of percentiles) }\end{array}$ & 2040 & 2060 & 2100 & 2040 & 2060 & 2100 \\
\hline Cth & 945 & 960 & 977 & 948 & 968 & 1019 \\
50th & 969 & 1002 & 1028 & 972 & 1009 & 1043 \\
95th & 1005 & 1028 & 1047 & 1005 & 1029 & 1065 \\
\hline
\end{tabular}

Table 2. The total cost for protection for the Charleston, SC example when the addition of a one-year storm surge is included in the protection cost. The incremental difference is representative of the increments experienced in locations throughout the study.

\begin{tabular}{|c|c|c|c|c|c|c|}
\hline \multirow{3}{*}{$\begin{array}{l}\text { Likelihood (in terms } \\
\text { of percentiles) }\end{array}$} & \multicolumn{3}{|c|}{ RCP 2.6} & \multicolumn{3}{|c|}{$\mathrm{RCP} 4.5$} \\
\hline & 2040 & 2060 & 2100 & 2040 & 2060 & 2100 \\
\hline & \multicolumn{3}{|c|}{ Cost in Millions USD } & \multicolumn{3}{|c|}{ Cost in Millions USD } \\
\hline 5 th & 1027 & 1029 & 1032 & 1027 & 1030 & 1044 \\
\hline 50th & 1031 & 1036 & 1047 & 1031 & 1038 & 1059 \\
\hline 95th & 1038 & 1047 & 1064 & 1038 & 1048 & 1075 \\
\hline
\end{tabular}

\section{Results}

In this section, the results of the SLR study are presented at the national, state, and city levels to emphasize the multi-jurisdictional impact of SLR. As detailed in the methodology section, the current study analyzed 36 different climate projections to determine the potential impacts of SLR and storm surge. The analysis presented in the following sections 
is based on future projections of median floodwater depths, computed as the superposition of SLR and 1-year storm surge, targeting both 2040 and 2100 under RCP 4.5.

\subsection{National Results}

The national results focused on the lower 48 states are presented in terms of regional groups to ensure consistency with the underlying datasets utilized in the study. The first of these regions, the western states (California, Oregon, and Washington), see a combined impact of USD 53.5 billion by 2040, with Washington having the largest impact with a potential impact of USD 23.9 billion. While this region is not discussed as often as the Atlantic coast and Gulf coast states, the impact should not be minimized. Washington and California are ranked 7th and 8th, respectively, in terms of potential impacts from SLR and storm surge by 2040.

The Gulf coast states (Texas, Louisiana, Mississippi, Alabama, and Florida) see a combined impact of USD 142.9 billion by 2040, with Florida having the largest impact with a potential cost of USD 75.9 billion as the top ranked state for impact under this scenario. This region has received considerable focus for climate impact due to the potentially large impact on tourism and property values of coastal real estate [30]. However, the projected impact of SLR grows significantly larger when the cost of protecting assets beyond real estate to include infrastructure as a general category is considered.

The southern half of the Atlantic states (Virginia, North Carolina, South Carolina, and Georgia) account for USD 101.2 billion in costs by 2040. Notable among this group are North Carolina and Virginia, which rank 3rd and 4th in projected costs, respectively. This region is already incurring damage-related costs in the billions of dollars due to increased nuisance flooding, as well as from recent hurricanes. However, the projected impact from chronic SLR issues must not be overlooked. The long-term cost of chronic impacts will likely surpass those of one-time events.

Finally, the northern half of the Atlantic states (Maine, New Hampshire, New York, Massachusetts, Rhode Island, Connecticut, Delaware, Pennsylvania, New Jersey, Washington DC, and Maryland) account for the remaining USD 118.7 billion. This region is notable for having states with considerable coastal infrastructure that requires protection such as in Maryland and New Jersey. In these locations, as in many of the high-cost states, infrastructure has been constructed over time in low-lying areas that extends to the coast with little or no buffer areas to protect property and infrastructure.

\subsection{State Results}

As illustrated in Table 3, Florida, Louisiana, and North Carolina are the top three states in terms of projected protection costs and kilometers of protection required. Each of these states have extensive low-lying areas that exist together with the extensive infrastructure that has been built in the low-lying areas. While these vulnerabilities have been exposed in large events such as hurricanes, the potential risk from the topography is increased when the impact of SLR and storm surge is taken into account.

Table 3. Protection cost and kilometers of protection required per state at 2040 and 2100 using the RCP 4.5 scenario at $50 \%$ to provide a mid-range estimate.

\begin{tabular}{ccccc}
\hline State & $\begin{array}{c}\mathbf{2 0 4 0} \\
\text { (Billions USD) }\end{array}$ & $\begin{array}{c}\mathbf{2 0 4 0} \\
\text { (Kilometers) }\end{array}$ & $\begin{array}{c}\mathbf{2 1 0 0} \\
\text { (Billions USD) }\end{array}$ & $\begin{array}{c}\mathbf{2 1 0 0} \\
\text { (Kilometers) }\end{array}$ \\
\hline Florida & 75.9 & 14,875 & 109.4 & 20,543 \\
Louisiana & 38.4 & 10,885 & 42.3 & 11,915 \\
North Carolina & 34.8 & 8449 & 36.7 & 8696 \\
Virginia & 31.2 & 6538 & 37.7 & 7930 \\
Maryland & 27.4 & 4821 & 36.0 & 6160 \\
New Jersey & 25.0 & 4338 & 29.3 & 4842 \\
\hline
\end{tabular}


Table 3. Cont.

\begin{tabular}{ccccc}
\hline State & $\begin{array}{c}\mathbf{2 0 4 0} \\
\text { (Billions USD) }\end{array}$ & $\begin{array}{c}\mathbf{2 0 4 0} \\
\text { (Kilometers) }\end{array}$ & $\begin{array}{c}\mathbf{2 1 0 0} \\
\text { (Billions USD) }\end{array}$ & $\begin{array}{c}\mathbf{2 1 0 0} \\
\text { (Kilometers) }\end{array}$ \\
\hline Washington & 23.9 & 2657 & 28.2 & 3159 \\
California & 22.0 & 2872 & 27.3 & 3611 \\
South Carolina & 20.1 & 5153 & 22.3 & 5436 \\
Texas & 19.3 & 4407 & 26.6 & 5845 \\
Massachusetts & 18.7 & 2077 & 24.0 & 2565 \\
New York & 17.4 & 2030 & 24.0 & 2774 \\
Georgia & 15.1 & 3958 & 15.8 & 4058 \\
Maine & 11.0 & 2039 & 13.8 & 2520 \\
Delaware & 9.4 & 1514 & 10.1 & 1612 \\
Oregon & 7.6 & 1105 & 9.8 & 1404 \\
Alabama & 6.0 & 963 & 7.7 & 1194 \\
Connecticut & 5.3 & 634 & 6.7 & 804 \\
Mississippi & 3.3 & 645 & 4.4 & 796 \\
Rhode Island & 2.9 & 397 & 4.0 & 553 \\
New Hampshire & 1.0 & 196 & 1.2 & 228 \\
Pennsylvania & 0.5 & 106 & 1.0 & 48 \\
Washington DC & 0.14 & 33 & 0.2 & 96,913 \\
TOTAL & 416.34 & 80,703 & 518.5 & \\
\hline
\end{tabular}

\subsection{City Results}

The results for individual cities are presented in this section in multiple formats, including the total costs and the costs per-capita. These multiple perspectives were created by translating the underlying grids from the study of the geographic boundaries specified by the Census Bureau (Data obtained from the US Census Bureau at https:/ / www.census. gov/geographies/mapping-files/time-series/geo/tiger-line-file.html, accessed on 10 June 2019). Table 4 presents the top 20 cities in terms of total cost that are at risk from SLR and storm surge based on the medium projection scenario.

Table 4. Protection cost for the Top 20 cities at 2040 using the RCP 4.5 scenario at 50\%.

\begin{tabular}{cccc}
\hline Rank & City & State & $\begin{array}{c}\mathbf{2 0 4 0} \\
\text { (Millions USD) }\end{array}$ \\
\hline 1 & Jacksonville & FL & 3461 \\
2 & New York & NY & 1974 \\
3 & Virginia Beach & VA & 1717 \\
4 & Marathon & FL & 1507 \\
5 & Fire Island & NY & 1450 \\
6 & Galveston & TX & 1058 \\
7 & Charleston & SC & 1032 \\
8 & Bolivar Peninsula & TX & 967 \\
9 & Tampa & FL & 938 \\
10 & Barnstable Town & MA & 889 \\
11 & Corpus Christi & TX & 861 \\
12 & North Key Largo & FL & 826 \\
13 & Poquoson & VA & 821 \\
14 & FL & 811 \\
15 & Islamorad Village of Islands & FL & 751 \\
16 & St. Petersburg & LA & 725 \\
17 & New Orleans & NC & 724 \\
18 & North Topsail Beach & AL & 718 \\
19 & Mobile & WA & 716 \\
20 & Seattle & NC & 708 \\
& Ocracoke & & 22,654 \\
\hline
\end{tabular}


The city ranking in Table 4 is critically affected by the inclusion of inland waterways in the assessment of coastal exposure, as demonstrated by the scores of Jacksonville, New York City, Virginia Beach, and Charleston. Cities that are located on islands (Marathon, FL, Fire Island, NY, and Galveston, TX) also occupy the top spots as a consequence of the significant extension of protection requirements.

The top 20 cities not only represent a diversity of geography, but also represent a diversity in costs per capita and costs per square area. Table 5 highlights a different perspective on the top twenty cities by highlighting those with the highest costs per capita. Many of these locations are either small towns located on islands, or beach towns located on coastal or inland waterways. These results highlight a challenge for policy makers as to where to prioritize limited protection funds. Should priority be given to popular tourist areas with small populations, but a large risk factor, or should priority be given to urban areas that provide a larger return-on-investment ratio in terms of the protection costs to area and population.

Table 5. Costs per capita at the city level in 2040 under the RCP 4.5 scenario at 50\%. Minimum 100 population.

\begin{tabular}{|c|c|c|c|c|}
\hline Rank. & City & State & $\begin{array}{c}2010 \text { Population } \\
\text { (US Census Bureau) }\end{array}$ & $\begin{array}{l}2040 \text { Costs per Capita } \\
\text { (Millions USD) }\end{array}$ \\
\hline 1 & Fire Island & NY & 246 & 5.89 \\
\hline 2 & Dames Quarter & $\mathrm{MD}$ & 157 & 3.89 \\
\hline 3 & Frenchtown-Rumbly & MD & 133 & 2.65 \\
\hline 4 & Gilgo & NY & 146 & 1.99 \\
\hline 5 & Ocracoke & $\mathrm{NC}$ & 404 & 1.75 \\
\hline 6 & Fairmount & MD & 306 & 1.46 \\
\hline 7 & Napeague & NY & 129 & 1.28 \\
\hline 8 & Bald Head Island & $\mathrm{NC}$ & 225 & 1.09 \\
\hline 9 & Fishers Island & NY & 230 & 0.97 \\
\hline 10 & St. George Island & FL & 740 & 0.91 \\
\hline 11 & Cameron Parish & LA & 222 & 0.87 \\
\hline 12 & North Key Largo & FL & 1009 & 0.82 \\
\hline 13 & Topsail Beach & $\mathrm{NC}$ & 366 & 0.74 \\
\hline 14 & North Topsail Beach & $\mathrm{NC}$ & 1061 & 0.68 \\
\hline 15 & Deal Island & MD & 465 & 0.66 \\
\hline 16 & Asharoken & NY & 446 & 0.65 \\
\hline 17 & Aripeka & FL & 111 & 0.62 \\
\hline 18 & Taylors Island & MD & 201 & 0.61 \\
\hline 19 & Gwynn & VA & 426 & 0.58 \\
\hline 20 & Strathmere & NJ & 257 & 0.54 \\
\hline
\end{tabular}

The projected costs per population highlight the challenge of small cities in terms of the cost of protection versus the size of the city. The same challenge exists in terms of the size of the town in comparison to the threats facing the location. Table 6 lists the 20 communities at least 2.6 square kilometers in size with highest costs per square kilometer. All but one of these communities is predicted to have costs that exceed USD 100 million to protect in 2040 .

Table 6. Costs per square kilometer at the city level in 2040 under the RCP 4.5 scenario at 50\%. Minimum 2.6 square kilometers in land area.

\begin{tabular}{ccccc}
\hline Rank & City & State & $\begin{array}{c}\text { Land Area } \\
\text { (Sq. Kms.) }\end{array}$ & $\begin{array}{c}\text { 2040 Per Sq. Km } \\
\text { (Millions USD) }\end{array}$ \\
\hline 1 & Fire Island & NY & 23.8 & 61.1 \\
2 & Holden Beach & NC & 7.1 & 60.1 \\
3 & Holmes Beach & FL & 4.4 & 59.6 \\
4 & Wrightsville Beach & NC & 3.6 & 59.5 \\
5 & North Beach Haven & NJ & 4.7 & 57.3 \\
6 & St. George Island & FL & 12.3 & 54.8 \\
\hline
\end{tabular}


Table 6. Cont.

\begin{tabular}{ccccc}
\hline Rank & City & State & $\begin{array}{c}\text { Land Area } \\
\text { (Sq. Kms.) }\end{array}$ & $\begin{array}{c}\text { 2040 Per Sq. Km } \\
\text { (Millions USD) }\end{array}$ \\
\hline 7 & Old Field & NY & 5.36 & 51.8 \\
8 & Nahant & MA & 2.7 & 49.8 \\
9 & Piney Point & MD & 4.0 & 48.6 \\
10 & Islamorada, Village of Islands & FL & 16.7 & 48.6 \\
11 & Big Coppitt Key & FL & 3.0 & 45.6 \\
12 & North Topsail Beach & NC & 16.1 & 45.1 \\
13 & Rehoboth Beach & DE & 3.1 & 42.6 \\
14 & Dauphin Island & AL & 16.2 & 42.5 \\
15 & Gwynn & VA & 6.1 & 40.7 \\
16 & Duck & NC & 6.3 & 40.7 \\
17 & Tavernier & FL & 6.5 & 40.1 \\
18 & Deal Island & MD & 7.9 & 39.1 \\
19 & Westbrook Center & CT & 4.4 & 39.1 \\
20 & Belford & NJ & 3.3 & 37.0 \\
\hline
\end{tabular}

\section{Discussion}

The protection of the coastline across 23 states with coastal exposure is a significant task that will require the cooperation of national, regional, and local entities. An intermediate climate scenario in 2040 projects that every coastal-facing state is threatened by sea level rise and storm surge at a national cost conservatively placed at USD 416 billion. This estimate grows to USD 518 billion dollars when the same scenario is extended to 2100 . This projection does not include maintenance costs, future replacement costs, or potential inflationary pressures due to a limitation of material or personnel resources.

This exposure elevates the SLR issue from a local problem that places the burden on local officials to a national issue that requires collaboration at all levels. This study highlighted a middle-of-the-road projection in 2040 and 2100 to emphasize a likely scenario of costs that jurisdictions will face by 2040. As illustrated in this study, the majority of states incur the primary protection costs by 2040, and only a few see significant increases in 2100 .

Complementing the focus on states is a deeper focus on coastal cities. Whereas cities such as New York City, San Francisco, and Miami are often the focus of SLR concerns, the risks of SLR go beyond these limited examples. The current study addresses this oversight by specifically addressing coastal cities of all sizes. The analysis highlights the particular concern for the small islands and coastal areas that either line the coast or lie adjacent to the mainland in areas along the Atlantic coast in particular. These areas often have small populations, but are popular tourist destinations, have individuals with longstanding family ties to the area, or may be small communities of very wealthy individuals. Protecting these areas, in particular the islands, can translate to significant costs when put in the context of the size of the area.

The following sections focus on three specific issues that emerge from the current study: the response timeline, the urban versus rural challenge, and the protection options challenge.

\subsection{Response Timeline}

A key message developed in this study is that the timeline for responding to the threat of sea level rise and storm surge begins now. The data for all alternative projections included within this study indicates that SLR and storm surge will have a national impact by 2040 in the majority of locations. In addition to the projected cost factor, there is considerable effort required to plan and design for protective barriers. Issues such as environmental impacts, site-specific engineering solutions, and the availability of expertise will extend the time required to implement protection solutions. 
Given that additional cost and time will be required for almost all of the protection projects, consideration must be given to initiating discussions on this issue if they are not already started. The study indicates that within 20 years, approximately $80 \%$ of the protection needed by 2100 to protect infrastructure from the SLR risk will already be required. In terms of the number of kilometers of protection required by 2040 , there is a projected need for over $80,000 \mathrm{~km}$ of protection. This projection only increases by $15 \%$ to just over 96,000 by 2100 . This increase reduces to $10 \%$ or less in states including Delaware, Louisiana, New Jersey, North Carolina, South Carolina, and Georgia.

The overall message being that the timeline for decision making is sooner rather than later. The majority of impacts to infrastructure will occur by 2040.

\subsection{Urban versus Rural}

The second challenge arising from the current study is the issue of where to prioritize protection from SLR and storm surge. As documented previously, depending on the perspective chosen, the cities at greatest risk will change in terms of cost. Smaller, remote island communities can be viewed as significantly higher in cost when viewed from a perspective of per-square-kilometer costs. In contrast, coastal cities such as Jacksonville, Florida have a much smaller investment when viewed on a per-square-kilometer basis. This would indicate that the relative cost of protecting the infrastructure in Jacksonville is less than that facing a small coastal island community. When viewed from a perspective of population, small coastal cities are a much more significant investment than larger coastal communities, especially when placed in the context of a costs per capita investment. Finally, from a total cost perspective, the perspective changes with cities such as Miami, which are spread along the coast rather than having a compact waterfront. Each of these perspectives is valid but requires a different prioritization of funding.

\subsection{Protection Feasibility and Options}

The final issue that is highlighted here is the issue of whether defensive seawalls are the appropriate approach to protecting communities, in particular smaller communities. With $80,000 \mathrm{~km}$ of seawall to construct by 2040 , the issue arises as to the feasibility of constructing this volume of protection in time and whether this is the correct approach. The issue of feasibility gives rise to multiple concerns, including those for the availability of design and construction personnel, for the availability of materials, and for potential price increase due to micro-inflationary pressures. However, an overriding question exists as to whether every community should undertake such a defensive endeavor.

This study focuses on the potential to protect infrastructure from SLR and storm surge. However, the remaining two options, retreat and accommodate, cannot be discounted as viable options. Significant attention is currently being placed on the concepts of managed retreat where communities strategically move away from vulnerable locations along the coastline [31-33]. These strategies emphasize the advantage of placing communities in safer locations rather than expending large amounts of resources on protection which may not be sufficient in the long-term.

In contrast to retreating, accommodating focuses on utilizing topography and water channeling efforts to manage the rising sea around an urban area. This approach focuses on considering options such as canals and raised structures to coexist with the rising sea level [34-36]. The argument for this approach being those examples such as Venice and Amsterdam which have demonstrated over centuries that accommodation can be effective given the planning and strategic management of the solution. Additionally, the solution can be implemented over an extended period of time rather than a large investment that is required for protection.

The ultimate decision as to which approach to take will likely be made at a local level. While each approach has advantages and disadvantages, the underlying focus remains consistent that a strategy is required to address the real threat of SLR. 


\subsection{Limitations}

The cost estimates presented here are considered conservative in that they are estimated construction costs that may increase due to specific conditions in local areas. The costs also do not include long-term maintenance costs or the potential for cost increases due to inflationary pressures. Thus, the actual costs incurred by municipalities is likely to be higher than the costs presented in this study.

\section{Conclusions}

The current study is intended to open a new conversation on the impact of sea level rise and storm surge. It is not focused on the science behind the SLR risks, nor does it intend to add to the scientific question of whether there will be SLR or how much SLR there might be. Rather, the current study addresses the critical question of what the potential impact of the projected SLR and storm surge is. In the same manner that public officials plan for earthquakes, hurricanes, floods, and tornadoes, SLR is a natural hazard that deserves a complete range of discussions including how to minimize the damage if and when such an event occurs. At a conservative projection of a USD 400 billion impact by 2040, SLR can no longer be ignored or treated as a purely theoretical argument by public officials responsible for the health and safety of the general public.

In addition to encouraging public officials to include SLR in planning discussions, this study should encourage communities of all sizes to consider the monetary commitment required for protection against SLR. Whether the community is limited in physical area and population or is one of the larger cities such as San Francisco, the impact of SLR will have significant financial impact.

The decision to address SLR is only the first step in addressing this complex issue. A single property owner, or even a single community, is not enough to address the overall threat from SLR. While a single owner may choose to retreat from the coastal area, or a community may elect to aggressively address SLR, this is an issue that requires cooperation and collaboration at the state, regional, and national levels. The successful implementation of a protection system requires neighboring communities and states to work together to ensure that engineered or natural systems work seamlessly along the coastline.

Author Contributions: Conceptualization of approach and oversight of costing, primary writing P.C.; oversight of modeling and development of flooding algorithms, J.H. All authors have read and agreed to the published version of the manuscript.

Funding: This research was funded by the Institute for Governance and Sustainable Development.

Institutional Review Board Statement: Not applicable.

Informed Consent Statement: Not applicable.

Data Availability Statement: A full set of final cost results used in this study is available at https: // climatecosts2040.org/data-sets.

Conflicts of Interest: The authors declare no conflict of interest.

\section{References}

1. Nicholls, R. Planning for the Impacts of Sea Level Rise. Oceanography 2011, 24, 144-157. [CrossRef]

2. US Department of Federal Highway Administration. Highways in the Coastal Environment; US Department of Federal Highway Administration: Washington, DC, USA, 2008; Volume 250.

3. Melillo, J.M.; Richmond, T.; Yohe, G.W. Climate Change Impacts in the United States: U.S. National Climate Assessment; US Global Change Research Program: Washington, DC, USA, 2014.

4. Jacobs, J.M.; Culp, M.; Cattaneo, L.; Chinowsky, P.S.; Choate, A.; DesRoches, S.; Douglass, S.L.; Miller, R. Chapter 12: Transportation. Impacts, Risks, and Adaptation in the United States: The Fourth National Climate Assessment, Volume II; U.S. Global Change Research Program: Washington, DC, USA, 2018.

5. US Department of Commerce, N. O. and A. A. (n.d.). How Long Is the U.S. Shoreline? Available online: https:/ /oceanservice. noaa.gov/facts/shorelength.html (accessed on 18 March 2019). 
6. Hauer, M.E.; Evans, J.M.; Mishra, D.R. Millions projected to be at risk from sea-level rise in the continental United States. Nat. Clim. Chang. 2016, 6, 691-695. [CrossRef]

7. Bamber, J.L.; Oppenheimer, M.; Kopp, R.E.; Aspinall, W.P.; Cooke, R.M. Ice sheet contributions to future sea-level rise from structured expert judgment. Proc. Natl. Acad. Sci. USA 2019, 116, 11195-11200. [CrossRef] [PubMed]

8. Schaeffer, M.; Hare, W.; Rahmstorf, S.; Vermeer, M. Long-term sea-level rise implied by $1.5^{\circ} \mathrm{C}$ and $2{ }^{\circ} \mathrm{C}$ warming levels. Nat. Clim. Chang. 2012, 2, 867-870. [CrossRef]

9. Fleming, E.; Payne, J.; Sweet, W.; Craghan, M.; Haines, J.; Hart, J.F.; Stiller, H.; Sutton-Grier, A. Coastal Effects. In Impacts, Risks, and Adaptation in the United States: Fourth National Climate Assessment, Volume II; Reidmiller, D.R., Avery, C.W., Easterling, D.R., Kunkel, K.E., Lewis, K.L.M., Maycock, T.K., Stewart, B.C., Eds.; U.S. Global Change Research Program: Washington, DC, USA, 2018; pp. 322-352. [CrossRef]

10. Neumann, B.; Vafeidis, A.T.; Zimmermann, J.; Nicholls, R.J. Future Coastal Population Growth and Exposure to Sea-Level Rise and Coastal Flooding-A Global Assessment. PLoS ONE 2015, 10, e0118571. [CrossRef]

11. Butler, W.H.; Deyle, R.E.; Mutnansky, C. Low-regrets incrementalism: Land use planning adaptation to accelerating sea level rise in Florida's Coastal Communities. J. Plan. Educ. Res. 2016, 36, 319-332. [CrossRef]

12. Yusuf, J.E.; Neill, K.; John, B.S.; Ash, I.K.; Mahar, K. The Sea Is Rising ... but Not onto the Policy Agenda: A Multiple Streams Approach to Understanding Sea Level Rise Policies. Environ. Plan. C: Gov. Policy 2016, 34, 228-243. [CrossRef]

13. Samuel, M.; Kartez, J.; Langbehn, K.; Muller-Karger, F.; Reynolds, C.J. Who should pay for climate adaptation? Public attitudes and the financing of flood protection in Florida. Environ. Values 2018, 27, 535-557.

14. Sutton-Grier, A.E.; Wowk, K.; Bamford, H. Future of our coasts: The potential for natural and hybrid infrastructure to enhance the resilience of our coastal communities, economies and ecosystems. Environ. Sci. Policy 2015, 51, 137-148. [CrossRef]

15. Griggs, G.B. The Impacts of Coastal Armoring. Shore Beach 2005, 73, 11.

16. Mcleod, E.; Poulter, B.; Hinkel, J.; Reyes, E.; Salm, R. Sea-level rise impact models and environmental conservation: A review of models and their applications. Ocean. Coast. Manag. 2010, 53, 507-517. [CrossRef]

17. Kirshen, P.; Merrill, S.; Slovinsky, P.; Richardson, N. Simplified method for scenario-based risk assessment adaptation planning in the coastal zone. Clim. Chang. 2012, 113, 919-931. [CrossRef]

18. Neumann, J.E.; Emanuel, K.; Ravela, S.; Ludwig, L.; Kirshen, P.; Bosma, K.; Martinich, J. Joint effects of storm surge and sea-level rise on US Coasts: New economic estimates of impacts, adaptation, and benefits of mitigation policy. Clim. Chang. 2014, 129, 337-349. [CrossRef]

19. Neumann, J.; Hudgens, D.; Herter, J.; Martinich, J. The economics of adaptation along developed coastlines: Adaptation along developed coastlines. Wiley Interdiscip. Rev. Clim. Chang. 2011, 2, 89-98. [CrossRef]

20. Neumann, J.E.; Hudgens, D.E.; Herter, J.; Martinich, J. Assessing Sea-Level Rise Impacts: A GIS-Based Framework and Application to Coastal New Jersey. Coast. Manag. 2010, 38, 433-455. [CrossRef]

21. Hsiang, S.; Kopp, R.; Jina, A.; Rising, J.; Delgado, M.; Mohan, S.; Rasmussen, D.J.; Muir-Wood, R.; Wilson, P.; Oppenheimer, M.; et al. Estimating economic damage from climate change in the United States. Science 2017, 356, 1362-1369. [CrossRef] [PubMed]

22. Cervigni, R.; Losos, A.M.; Neumann, J.L.; Chinowsky, P. Enhancing the Climate Resilience of Africa's Infrastructure: The Roads and Bridges Sector. Publication 2016, 110137, 1-0.

23. Chinowsky, P.; Helman, J.; Gulati, S.; Neumann, J.; Martinich, J. Impacts of climate change on operation of the US rail network. Transp. Policy 2019, 75, 183-191. [CrossRef]

24. Schweikert, A.; Espinet, X.; Chinowsky, P. The triple bottom line: Bringing a sustainability framework to prioritize climate change investments for infrastructure planning. Sustain. Sci. 2018, 13, 377-391. [CrossRef]

25. Kopp, R.E.; DeConto, R.M.; Bader, D.A.; Hay, C.C.; Horton, R.M.; Kulp, S.; Oppenheimer, M.; Pollard, D.; Strauss, B.H. Evolving understanding of Antarctic ice-sheet physics and ambiguity in probabilistic sea-level projections. Earth's Future 2017, 5, 1217-1233. [CrossRef]

26. Kulp, S.; Strauss, B.H. Global DEM errors underpredict coastal vulnerability to sea level rise and flooding. Front. Earth Sci. 2016, 4, 36. [CrossRef]

27. Tebaldi, C.; Strauss, B.H.; Zervas, C.E. Modelling sea level rise impacts on storm surges along US coasts. Environ. Res. Lett. 2012, 7, 014032. [CrossRef]

28. Hausfather, Z.; Peters, G.P. Emissions-the 'business as usual'story is misleading. Nature 2020, 577, 618-620. [CrossRef]

29. Strauss, B.H.; Ziemlinski, R.; Weiss, J.L.; Overpeck, J.T. Tidally adjusted estimates of topographic vulnerability to sea level rise and flooding for the contiguous United States. Environ. Res. Lett. 2012, 7, 014033. [CrossRef]

30. Gordian. Heavy Construction Costs with RS Means Data; R S Means Co.: Greenville, SC, USA, 2019.

31. McAlpine, S.A.; Porter, J.R. Estimating Recent Local Impacts of Sea-Level Rise on Current Real-Estate Losses: A Housing Market Case Study in Miami-Dade, Florida. Popul. Res. Policy Rev. 2018, 37, 871-895. [CrossRef] [PubMed]

32. Siders, A.R.; Hino, M.; Mach, K.J. The case for strategic and managed climate retreat. Science 2019, 365, 761-763. [CrossRef] [PubMed]

33. Carey, J. Core Concept: Managed retreat increasingly seen as necessary in response to climate change's fury. Proc. Natl. Acad. Sci. USA 2020, 117, 13182-13185. [CrossRef]

34. Ajibade, I.; Sullivan, M.; Haeffner, M. Why climate migration is not managed retreat: Six justifications. Glob. Environ. Chang. 2020, 65, 102187. [CrossRef] 
35. Tol, R.S.; Bohn, M.; Downing, T.E.; Guillerminet, M.L.; Hizsnyik, E.; Kasperson, R.; Lonsdale, K.; Mays, C.; Nicholls, R.J.; Olsthoorn, A.A.; et al. Adaptation to five metres of sea level rise. J. Risk Res. 2006, 9, 467-482. [CrossRef]

36. Dedekorkut-Howes, A.; Torabi, E.; Howes, M. When the tide gets high: A review of adaptive responses to sea level rise and coastal flooding. J. Environ. Plan. Manag. 2020, 63, 2102-2143. [CrossRef] 